\title{
Rural Communities Perceptions and Attitudes towards Environment Tourism Development
}

\author{
May-Chiun Lo ${ }^{1}$, T. Ramayah ${ }^{2} \&$ Helen Lee Hui Hui ${ }^{1}$ \\ ${ }^{1}$ Faculty of Economics and Business, Universiti Malaysia Sarawak, Sarawak, Malaysia \\ ${ }^{2}$ School of Management, Universiti Sains Malaysia, Penang, Malaysia \\ Correspondence: May-Chiun Lo, Faculty of Economics and Business, Universiti Malaysia Sarawak, 94300 \\ Sarawak, Malaysia. Tel: 60-82-58-1154. E-mail: mclo@feb.unimas.my
}

Received: September 23, 2013 Accepted: November 18, 2013 Online Published: July 31, 2014

doi:10.5539/jsd.v7n4p84

URL: http://dx.doi.org/10.5539/jsd.v7n4p84

\begin{abstract}
Past literature has posited that tourism is one of the fastest growing sectors and has been signified as an attractive investment proposition. Rural tourism sector has been actively promoted by the Malaysian government and currently, it is considered as one of the cornerstone of Malaysia's economic diversification strategy. On the other hand, it is important to note that stakeholder like local communities do play a crucial role in sustaining tourism development. Hence, the purpose of this study is to assess the impact of rural tourism development on the environment from the local communities' perspectives. The environmental constructs which consists of surrounding of therural tourism destination, environment management practice, conservation of culture heritage, local satisfaction and influence of resources have been examined against local communities' attitude towards rural tourism development. 199 respondents comprising of residents of rural tourism in Sarawak, Malaysia took part voluntarily in this study. To assess the developed model, SmarPLS 2.0 (M3) was applied based on path modelling and then bootstrapping with 200 re-samples was applied to generate the standard error of the estimate and t-values. Interestingly, the findings suggested that local communities were most concerned with the conservation of culture heritage and influence of resources when it comes to rural tourism development. Implications of these findings showed that it is crucial to understand the various concerns of the local communities for ensuring better sustainability performance especially in rural tourism setting.
\end{abstract}

\section{Introduction}

Tourism is considered as one of the corner stone industry and is ranked as the second largest industry in Malaysia. It plays a significant role in reducing the rate of poverty among the rural communities especially those in rural tourism destinations. Most significantly, rural tourism is seen as an opportunity for local people living in tourism destinations to gain positive benefits from tourism development and the state's conservation of forests and protected areas. Past studies have elucidated that the standard of living and employment opportunities of the rural communities depend very much on tourism industry (Bredhenhann \& Wickens, 2003; Ruiz Molina, Gil-Saura, \& Moliner-Velazquez, 2010). Nonetheless, tourism may bring negative impact to the local residents if it is not managed in a responsible way. In order to achieve a sustainable tourism development, local community leaders and stakeholders in tourism industry should work together to manage rural tourism industry as a 'community industry' (Murphy, 1985). Hence, for the tourism-related economy to sustain it and the residents to be satisfied, residents must be willing to take part in the process. Considering the frequency of interaction between residents and tourists, their willingness to serve as kind hosts is critical to the success of tourism. Therefore, residents are encouraged to be actively involved in the planning process and their attitudes toward tourism and perceptions of its impact on community life must be continually assessed to increase their satisfaction (Allen, Long, Perdue \& Kieselbach, 1988).

Tourism was promoted by the Malaysian government back in the 1970s, where the government started by focusing on providing basic infrastructures like highways, airports and the upgrading of attractions with potential tourism destination. In the 1980 's, tourism was promoted as a means to meet the country's development objectives, and now, the Malaysian government has launched the Economic Transformation Programme (ETP) as they foresee that there is a need to enhance connectivity to key priority tourism markets. Although government efforts play a 
crucial role in the development of tourism, it is undeniable that other stakeholders in the tourism industry contribute to the development decisions by ensuring the industry is managed in a responsible way.

The quality of the environment, both natural and man-made, is essential to tourism such as the construction of general infrastructure such as roads and airports, and tourism facilities, including resorts, hotels, restaurants, shops, golf courses and marinas. They may give adverse impact on tourism especially rural destinations. Past studies contended that if rural tourism is not planned properly, it will result in uncontrolled constructions and distorted urbanization at the destination, damage the natural environment and wildlife, and cause pollution to rivers. It was reported that the costs of preserving historical and cultural, the loss of wild life areas and natural landscape are very high (Tatoglu, Erdal, \& özgur, 2012).

The environment can be improved and achieved by ensuring that development is harmonious with the overall plan for the destination, increase the number of attractions, recreational opportunities and services (Batra \& Kaur, 1996; Eshliki \& Kabousi, 2012). Past studies (e.g., Buckley \& Pannell, 1990; Nunkoo \& Ramkissoon, 2010) have identified damage to the natural environment as one of the major detractants from the visitor's experience. Hence, an environmental protection strategy should be implemented to address the issue of eco-tourists from the cause-and-effect of their actions on the environment. More initiatives should be conducted and to be more cautious of the places they visit (Tuohino \& Hynonen, 2001; Greaves, 2010).

Thus, this paper focuses on the impact of rural tourism development on the environment from the local communities' perspectives, and how would that affect their attitudes. This study endeavors to evaluate the impact of environment construct namely, surrounding of rural tourism destination, environment management practice, conservation of culture heritage, local satisfaction and influence of resources on the local communities in rural tourism destination in Sarawak, Malaysia.

\section{Literature Review}

\subsection{Community Based Tourism}

Rural tourism is different from other forms of tourism where its development is dependent very much on the natural and social/cultural environments. In view of that, it is crucial to conserve and preserve the quality of tourism environment especially for rural tourism destinations. Community-based tourism has been actively promoted in many parts of the world especially in Asian countries, such as in Thailand, Cambodia, Mongolia, Malaysia, and Indonesia. Past studies have contended that other countries (e.g., Africa, Latin America, and the Caribbean) were found to have formed community-based tourism network in order to promote rural tourism (Jamaludinet al., 2012). Researchers in the past have defined community-based tourism where the communities are given certain authority to decide and protect the environment at the same time creating cross-cultural awareness (Tsonis, 2009) in order to promote the economic, social and cultural well being of the communities at the rural tourism destinations (Brohman, 1996). It is important to implement a balanced and harmonious approach to development of rural tourism, ensure the quality of development, both culturally and environmentally, and also focus on the needs, interest, and potentials of the community and its inhabitants for the sustainability of the rural tourism development (Razzaq, Hadi, Mustafa, Hamzah, Khalifah \& Mohamad, 2011).

\subsection{Environment}

Tourism environment has been broadly defined as the involvement in biophysical and socio-cultural environments (Zhong, Deng, Song \& Ding, 2011). It is evidenced that tourism development has resulted in economics, environmental, and social-cultural benefits to the local communities which helps to revitalize and improve on the standard of living of the local communities (Kuvan \& Akan, 2005; Andereck \& Vogt, 2000). Researchers in the past contended that an environmental protection strategy should be implemented to address the issue of eco-tourists from the cause-and-effect of their actions on the environment. Hence, more initiatives should be conducted to increase their awareness, sensitize them to environmental issues, and to be more cautious of the places they visit (Tuohino \& Hynonen, 2001).The Malaysian government has set up the Department of Environment (DOE) to implement the management of environment and to increase the awareness of the environmental impact of tourism (Mohammed, 2002).

On another note, in many developing economies, heritage is regarded as one of the more significant and fastest growing components of tourism (Alzue, O’Leary \& Morrison, 1998; Herbert, 2001). It has become increasingly popular in the world, and very important for tourism development. Cultural and heritage tourism is vital for economic development that achieves economic growth by attracting visitors from outside a host community, who are interested in the historical, artistic, scientific or lifestyle/heritage offerings of a community, region, group or institution (Silberberg, 1995). Cultural heritage conservation helps a community not only by protecting 
the valuable physical assets, but also preserving its practices, history, and environment, and a sense of continuity and identity. Prompt action should be taken to conserve the cultural heritage as the cultural property is more at risk from the secondary effects of a disaster than from the disaster itself. Many countries agreed that cultural/heritage tourism strategies can be used to boost local culture especially in rural destinations, and that they can aid the seasonal and geographic spread of tourism (Richards, 1996).

Local communities' satisfaction is known as part of the environmental component in managing rural tourism destination. As tourism development usually involves a compromise between economic benefits and environmental or cultural costs, residents can manage by emphasizing the economic gains to maintain satisfaction with their community (Dyer et al., 2007; Cavus \& Tanrisevdi, 2002; Faulkner \& Tideswell, 1997).Hence, in order to maintain sustainability and long term success of the tourism industry, local communities should participate in understanding and assessing tourism impact at their destinations (Diedrich \& Garc1'a-Buades, 2008).

On another note, natural resources play a significant role in environmental management of tourism industry. Researchers in the past (e.g., Hull \& Revall, 1989) stressed the importance of landscape and defined it as the outdoor environment, natural or built as perceived by the tourists of the rural destinations (Jaal \& Abdullah, 2012). Studies have evidenced that tourism has resulted in negative impacts on the environment, such as erosion and environmental degradation due to the uncontrolled construction, littering, fire risks, and vandalism. It was reported that teahouses, small supermarkets, guesthouses, and handicraft shops were opened at the tourism destinations which are not managed by the communities as they haveno capacity to run and accommodate them (Ghaderi \& Henderson, 2012).

\subsection{Attitude of Local Communities towards Tourism}

Huang and Stewart (1996) mentioned that tourism development may alter the residents' relationships to one another and to their community. It is observed that the perception and attitudes of residents toward the impacts of tourism are important to the planning and policy consideration for successful development, marketing, and operation of existing and future tourism program (Ap, 1992). Residents with the most economic gain will be most supportive of the tourism industry (Harrill, 2004). Cavus and Tanrisevdi (2002) found that the development process was the primary factor in residents' negative attitudes towards tourism. When residents perceive that the costs of tourism overshadow the benefits, feelings of anger and irritation towards tourists can develop and thus lower community satisfaction (Doxey, 1975; Faulkner \& Tideswell, 1997; Ko \& Stewart, 2002). Residents who feel that they are participating in tourism planning on the other hand will have more positive attitudes towards tourism (Cavus \& Tanrisevdi, 2002).

In spite of this, the findings show that the majority of local residents perceived tourism as an economic development tool (Gursoy et al., 2002), and thus it is not surprising that most of the findings on resident attitudes toward srural tourism development shows a positive assertiveness (Andereck \& Vogt, 2000) while only a few studies reported negative attitude toward tourism. To ensure long-term success in tourism development, it is very essential to have the local residents' support. It is impossible to sustain tourism to a destination that is not supported by the local people (Ahn, Lee \& Shafer, 2002; Twinning-Ward \& Butler 2002; McCool, Moisey \& Nickerson, 2001).

\section{Method}

To achieve the objectives of the study we collected data from local community in rural tourism destinations in Sarawak. A total of 199 responses were received and were found suitable for analysis. To test the hypotheses generated we used a second generation analysis technique called Partial Least Squares (PLS) which is also Structural Equation Modelling (SEM) which is more powerful than the first generation technique analysis. SmartPLS 2.0 (M3) (Ringle et al., 2005) a variance-based SEM technique was used to test the hypothesized relationships. Since PLS is a non-parametric technique the significance of the paths generated need to be analysed using a procedure called bootstrapping. Bootstrapping is a resampling technique that draws a largenumber of subsamples from the original data (with replacement) and estimates modelsfor each subsample and this is recommended by Hair et al. (2014) to compute a standard error of each modelparameter. From this calculated t-values we can then test whether the path coefficients are significant or not. 


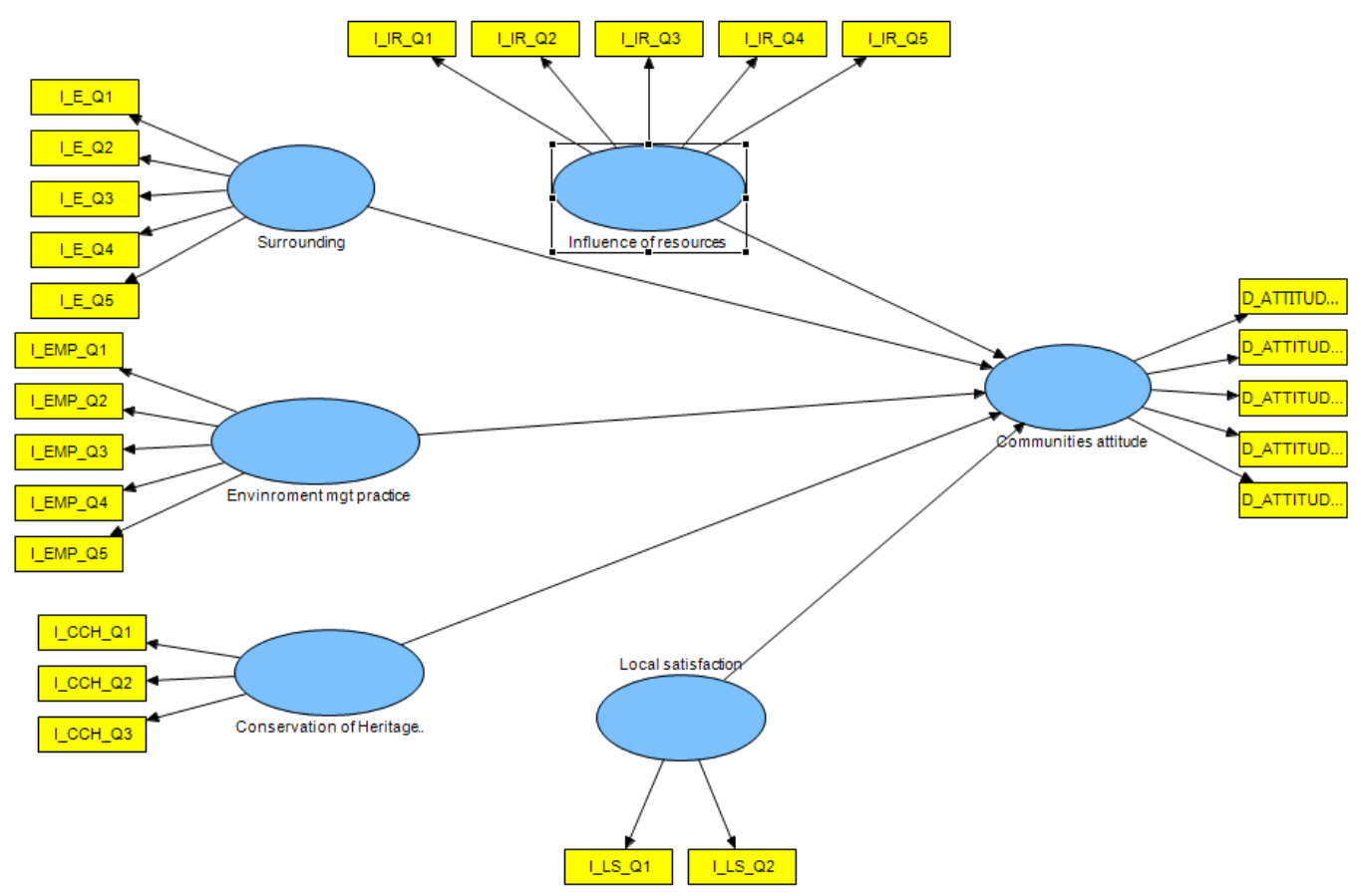

Figure 1. Research model

\subsection{Assessment of the Measurement Model}

Structural equation modelling analysis relies on a two-step procedure called measurement model and structural model analysis (Anderson \& Gerbing, 1981). The measurement model is used to assess the validity and reliability of the items used to measure the constructs. If the loadings are more than 0.5 (Hair et al., 2010), average variance extracted is more than 0.5 (Fornell \& Bookstein, 1982) and composite reliabilities are more than 0.7 (Chin, 2010) then we can assume that the measures are valid. From table 1 we can see that our measures all exceeded the cut-off values recommended in the literature. In addition, we calculated the square root of the AVE that exceeded the inter-correlations of the construct with the other constructs (Table 2), which ensured discriminant validity (Fornell \& Larcker, 1981). As suggested by Henseler et al. (2009), the second option for verifying discriminant validity is by examining that the loadings of the indicators should be higher than the cross loadings on other constructs (see Table 3). Thus we can be assured that the measures used are valid and reliable. 
Table 1. Results of measurement model

\begin{tabular}{|c|c|c|c|c|c|}
\hline Model Construct & Measurement Item & $\begin{array}{c}\text { Cronbach } \\
\text { Alpha }\end{array}$ & Loading & $\mathbf{C R}^{\mathrm{a}}$ & $\mathbf{A V E}^{\mathbf{b}}$ \\
\hline Communities' & & 0.818 & & 0.872 & 0.580 \\
\hline \multirow[t]{5}{*}{ Attitude } & Comm_Attitude 1 & & 0.799 & & \\
\hline & Comm_Attitude 2 & & 0.814 & & \\
\hline & Comm_Attitude 3 & & 0.855 & & \\
\hline & Comm_Attitude 4 & & 0.628 & & \\
\hline & Comm_Attitude 5 & & 0.686 & & \\
\hline Conservation of & & 0.704 & & 0.708 & 0.569 \\
\hline \multirow[t]{2}{*}{ Culture Heritage } & Con_Culture Heritage 1 & & 0.939 & & \\
\hline & Con_Culture Heritage 3 & & 0.508 & & \\
\hline Environment & & 0.716 & & 0.813 & 0.471 \\
\hline \multirow[t]{5}{*}{ Management Practice } & Env_Mange_Practice 1 & & 0.583 & & \\
\hline & Env_Mange_Practice 2 & & 0.815 & & \\
\hline & Env_Mange_Practice 3 & & 0.646 & & \\
\hline & Env_Mange_Practice 4 & & 0.776 & & \\
\hline & Env_Mange_Practice 5 & & 0.574 & & \\
\hline Surrounding & & 0.820 & & 0.873 & 0.580 \\
\hline \multirow[t]{5}{*}{ Tourism Destination } & Surrou_Destination 1 & & 0.727 & & \\
\hline & Surrou_Destination 2 & & 0.792 & & \\
\hline & Surrou_Destination 3 & & 0.734 & & \\
\hline & Surrou_Destination 4 & & 0.808 & & \\
\hline & Surrou_Destination 5 & & 0.743 & & \\
\hline Influence of & & 0.785 & & 0.853 & 0.538 \\
\hline \multirow[t]{5}{*}{ Resources } & Influence_Resources 1 & & 0.711 & & \\
\hline & Influence_Resources 2 & & 0.832 & & \\
\hline & Influence_Resources 3 & & 0.696 & & \\
\hline & Influence_Resources 4 & & 0.719 & & \\
\hline & Influence_Resources 5 & & 0.702 & & \\
\hline \multirow[t]{3}{*}{ Local Satisfaction } & & 0.836 & & 0.923 & 0.857 \\
\hline & Local_Satisfaction 1 & & 0.903 & & \\
\hline & Local_Satisfaction 1 & & 0.948 & & \\
\hline
\end{tabular}

Note:

a Composite reliability $\mathbf{( C R})=$ (square of the summation of the factor loadings $) /$ ( (square of the summation of the factor loadings) + (summation of error variances) $\}$.

b Average variance extracted $(\mathbf{A V E})=($ summation of the square of the factor loadings $) /$ \{summation of the square of the factor loadings $\}+$ (summation of error variances) $\}$. 
Table 2. Discriminant validity of constructs

\begin{tabular}{|c|c|c|c|c|c|c|}
\hline Constructs & $\begin{array}{l}\text { Communities' } \\
\text { Attitude }\end{array}$ & $\begin{array}{l}\text { Conservation } \\
\text { of Culture } \\
\text { Heritage }\end{array}$ & $\begin{array}{l}\text { Environment } \\
\text { Management } \\
\text { Practice }\end{array}$ & $\begin{array}{l}\text { Surrounding } \\
\text { of Tourism } \\
\text { Destination }\end{array}$ & $\begin{array}{l}\text { Influence } \\
\text { of } \\
\text { Resources }\end{array}$ & $\begin{array}{c}\text { Local } \\
\text { Satisfaction }\end{array}$ \\
\hline $\begin{array}{l}\text { Communities' } \\
\text { Attitude }\end{array}$ & 0.762 & & & & & \\
\hline $\begin{array}{l}\text { Conservation } \\
\text { Culture Heritage }\end{array}$ & 0.496 & 0.754 & & & & \\
\hline $\begin{array}{l}\text { Environment } \\
\text { Management } \\
\text { Practice }\end{array}$ & 0.527 & 0.429 & 0.686 & & & \\
\hline $\begin{array}{l}\text { Surrounding of } \\
\text { Tourism Destination }\end{array}$ & 0.469 & 0.474 & 0.507 & 0.762 & & \\
\hline $\begin{array}{l}\text { Influence } \quad \text { of } \\
\text { Resources }\end{array}$ & 0.586 & 0.483 & 0.618 & 0.600 & 0.733 & \\
\hline Local Satisfaction & 0.132 & 0.129 & 0.088 & 0.039 & 0.018 & 0.926 \\
\hline
\end{tabular}

Note: Diagonals represent the square root of the average variance extracted while the other entries represent the correlations.

Table 3. Loading and cross loading

\begin{tabular}{lcccccc}
\hline & $\begin{array}{c}\text { Communities' } \\
\text { Attitude }\end{array}$ & $\begin{array}{c}\text { Conservation } \\
\text { of Culture } \\
\text { Heritage }\end{array}$ & $\begin{array}{c}\text { Environment } \\
\text { Management } \\
\text { Practice }\end{array}$ & $\begin{array}{c}\text { Surrounding } \\
\text { of Tourism } \\
\text { Destination }\end{array}$ & $\begin{array}{c}\text { Influence } \\
\text { of } \\
\text { Resources }\end{array}$ & $\begin{array}{c}\text { Local } \\
\text { Satisfaction }\end{array}$ \\
\hline Comm_Attitude 1 & $\mathbf{0 . 7 9 9}$ & 0.408 & 0.496 & 0.340 & 0.532 & 0.024 \\
Comm_Attitude 2 & $\mathbf{0 . 8 1 4}$ & 0.430 & 0.436 & 0.426 & 0.463 & 0.120 \\
Comm_Attitude 3 & $\mathbf{0 . 8 5 5}$ & 0.396 & 0.490 & 0.400 & 0.547 & 0.140 \\
Comm_Attitude 4 & $\mathbf{0 . 6 2 8}$ & 0.308 & 0.269 & 0.246 & 0.263 & 0.156 \\
Comm_Attitude 5 & $\mathbf{0 . 6 8 6}$ & 0.331 & 0.237 & 0.357 & 0.354 & 0.086 \\
Con_Culture Heritage 1 & 0.488 & $\mathbf{0 . 9 3 9}$ & 0.395 & 0.448 & 0.494 & 0.077 \\
Con_Culture Heritage 3 & 0.195 & $\mathbf{0 . 5 0 8}$ & 0.237 & 0.232 & 0.143 & 0.175 \\
Env_Mange_Practice 1 & 0.266 & 0.167 & $\mathbf{0 . 5 8 3}$ & 0.428 & 0.361 & 0.264 \\
Env_Mange_Practice 2 & 0.455 & 0.293 & $\mathbf{0 . 8 1 5}$ & 0.431 & 0.620 & -0.026 \\
Env_Mange_Practice 3 & 0.324 & 0.307 & $\mathbf{0 . 6 4 6}$ & 0.287 & 0.435 & -0.091 \\
Env_Mange_practice 4 & 0.445 & 0.422 & $\mathbf{0 . 7 7 6}$ & 0.402 & 0.431 & 0.077 \\
Env_Mange_practice 5 & 0.257 & 0.239 & $\mathbf{0 . 5 7 4}$ & 0.156 & 0.186 & 0.175 \\
Surrou_Destination 1 & 0.281 & 0.317 & 0.338 & $\mathbf{0 . 7 2 7}$ & 0.441 & -0.009 \\
Surrou_Destination 2 & 0.447 & 0.417 & 0.410 & $\mathbf{0 . 7 9 2}$ & 0.567 & -0.035 \\
Surrou_Destination 3 & 0.285 & 0.317 & 0.316 & $\mathbf{0 . 7 3 4}$ & 0.390 & 0.024 \\
Surrou_Destination 4 & 0.393 & 0.414 & 0.450 & $\mathbf{0 . 8 0 8}$ & 0.491 & 0.074 \\
Surrou_Destination 5 & 0.333 & 0.310 & 0.391 & $\mathbf{0 . 7 4 3}$ & 0.355 & 0.104 \\
Influence_Resources 1 & 0.445 & 0.264 & 0.540 & 0.361 & $\mathbf{0 . 7 1 1}$ & -0.153 \\
Influence_Resources 2 & 0.452 & 0.509 & 0.574 & 0.529 & $\mathbf{0 . 8 3 2}$ & -0.026 \\
Influence_Resources 3 & 0.334 & 0.335 & 0.378 & 0.335 & $\mathbf{0 . 6 9 6}$ & -0.179 \\
Influence_Resources 4 & 0.457 & 0.366 & 0.438 & 0.505 & $\mathbf{0 . 7 1 9}$ & 0.268 \\
Influence_Resources 5 & 0.439 & 0.290 & 0.315 & 0.443 & $\mathbf{0 . 7 0 2}$ & 0.103 \\
Local_Satisfaction 1 & 0.103 & 0.088 & 0.133 & 0.069 & 0.020 & $\mathbf{0 . 9 0 3}$ \\
Local_Satisfaction 2 & 0.138 & 0.143 & 0.044 & 0.013 & 0.014 & $\mathbf{0 . 9 4 8}$ \\
\hline & & & & & \\
\hline
\end{tabular}




\subsection{Assessment of the Structural Model}

Next we looked at the inner model to test the hypotheses that were generated. Figure 2 shows the visual results while Table 4 shows the detailed results.Environmental management practices $(\beta=0.194, \mathrm{t}=1.764)$, conservation of cultural heritage $(\beta=0.213, t=2.288)$ and Influence of $\operatorname{Resources}(\beta=0.316, t=3.190)$ were significant predictors of communities' attitude whereas surroundings of tourism and local satisfaction were not significant. Thus $\mathrm{H} 2, \mathrm{H} 3$ and $\mathrm{H} 5$ were supported while $\mathrm{H} 1$ and $\mathrm{H} 4$ were not supported. The $\mathrm{R}^{2}$ value was 0.440 which indicates that $44 \%$ of the variance in the communities' attitude can be explained by all the five constructs. The most important predictor was influence of resources followed by conservation of cultural heritage.

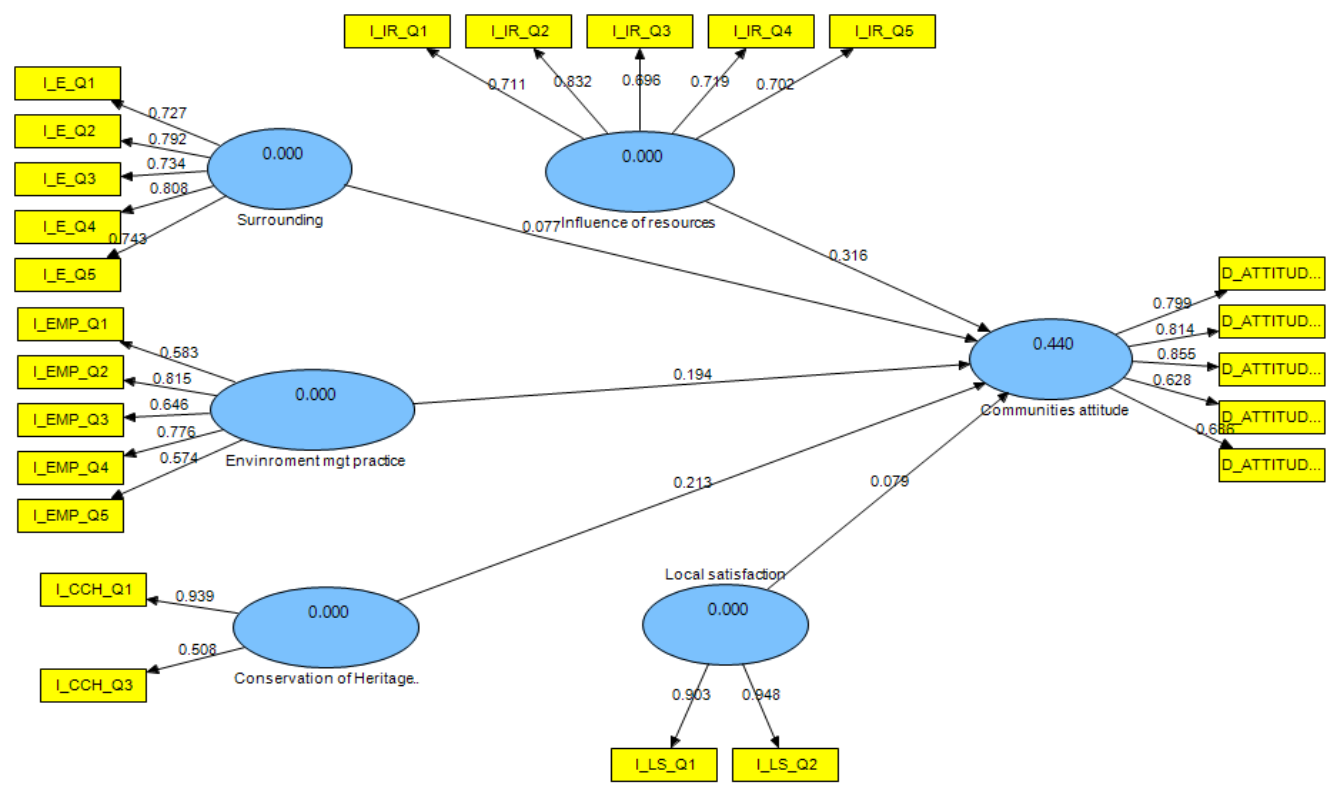

Figure 2. Results of the path analysis

Table 4. Path coefficients and hypothesis testing

\begin{tabular}{llccc}
\hline Hypothesis & Relationship & Coefficient & t-value & Supported \\
\hline H1 & $\begin{array}{l}\text { Surroundings } \\
\text { destination } \rightarrow \text { communities' attitude }\end{array}$ & 0.077 & 0.678 & NO \\
H2 & $\begin{array}{l}\text { Environment Management Practice } \rightarrow \\
\text { communities' attitude }\end{array}$ & 0.194 & $1.764^{*}$ & YES \\
H3 & $\begin{array}{l}\text { Conservation of Cultural Heritage } \rightarrow \\
\text { communities' attitude }\end{array}$ & 0.213 & $2.288^{*}$ & YES \\
H4 & $\begin{array}{l}\text { Local Satisfaction } \rightarrow \text { communities' attitude } \\
\text { Influence of Resources } \rightarrow \text { communities' } \\
\text { attitude }\end{array}$ & 0.079 & 0.992 & NO \\
& & & $3.190^{* *}$ & YES \\
\hline$* \mathrm{p}<0.01,{ }^{*} \mathrm{p}<0.05$ & & &
\end{tabular}

\section{Discussion}

Communities are known as the most important stakeholder in the tourism industry as they are the ones who will be most affected by the decisions with regards to tourism planning and development of their areas. Hence, understanding community attitudes are vital for the sustainability of rural tourism development (Eshliki \& Kaboudi, 2012). This study aims to investigate the extent of tourism impact on the destinations' environment and how that would affect communities' perceptions towards the development of rural tourism. It is believed that these perceptions would assist policy and decision makers when it comes to tourism planning and development. 
Past studies have envisaged that the development of tourism has seriously affected the environment of the destinations (Song, Lee, Kang, \& Boo, 2012). Hence, it is proposed that more environmentally friendly practices be implemented to preserve and conserve the environment of the tourism destinations. This study has extended the existing knowledge on tourism research particularly rural tourism development in the Malaysian context. Five dimensions of environmental construct, namely, (1) surrounding of rural tourism destination; (2) environment management practice; (3) conservation of culturalheritage, (4) local satisfaction; and (5) influence of resources, were tested on communities' attitudes towards rural tourism development. These scales were tested on its capabilities in explaining sufficient variation in the construct being measured in the Malaysian rural tourism destinations in general and Sarawak in particular.

Interestingly, three dimensions, namely environmental management practices, conservation of cultural heritage and influence of resources were found to be statistically significant to communities' attitudes towards tourism development and are of the concern of local communities. These results are further supported by past researchers whereby the presence of congestion would bring adverse impact on conservation effort especially for the historical sites and this has caused stress on the local communities (Riganti \& Nijkamp, 2007).As stated by Bao and $\mathrm{Su}$ (2004), many issues in the past are related to cultural heritage such as over commercialization, crowding of heritage attractions, ignorance of residents about their benefits and effect on their daily life. All this negative impact resulting from tourism development has affected the perceptions of rural communities towards the development of their areas into tourism destinations.

On the other hand, the result has also indicated that another concern of the local communities are the impact of tourism development on their resources and the environmental management practices. This is congruent with past research whereby negative environmental impact such as littering, overcrowding, pollution of water and soil have caused damage to the natural resources thus affecting the communities (Liu, Sheldon \&Var, 1987; Mason, 2003; Aref, Redzuan \& Gill, 2009).

\section{Conclusion}

This study has provided compelling evidence on the importance of continuous efforts to understand the nature of rural tourism destinations from the perception of local communities. It is worth examining the impact tourism could have on local communities in view of the fact that identifying and developing sustainable rural tourism continues to be important in tourism industry. This research study claims to demonstrate the existence of a positive and significant link between two types of environmental factors namely, conservation of culture heritage and influence of resources on communities' attitudes towards tourism development. Hence, it is crucial to understand the various concerns of the local communities to ensure a better sustainability performance especially in rural tourism setting.

\section{Acknowledgement}

The funding for this project was made possible through the research grant obtained from the Ministry of Higher Education, Malaysia under the Long Term Research Grant Scheme 2011 [LRGS grant no: JPT.S (BPKI)2000/09/01/015Jld.4(67)].

\section{References}

Ahn, B., Lee, B., \& Shafer, C. S. (2002). Operationalising Sustainability in Regional Tourism Planning: An Application of the Limits of Acceptable Change Framework. Tourism Management, 23, 1-15. http://dx.doi.org/10.1016/S0261-5177(01)00059-0

Akter, S., D’Ambra, J., \& Ray, P. (2011). Trustworthiness in Health Information Services: An Assessment of a Hierarchical Model with Mediating and Moderating Effects Using Partial Least Squares (PLS). Journal of the American Society For Information Science And Technology, 62(1), 100-116. http://dx.doi.org/10.1002/asi.21442

Allen, L. R., Long, P. T., Perdue, R. R., \& Kieselbach, S. (1998). The impact of tourism development on residents' perceptions of community life. Journal of Travel Research, 27, 16-21. http://dx.doi.org/10.1177/004728758802700104

Alzue, A., O’Leary, J., \& Morrison, A. M. (1998). Cultural and heritage tourism: identifying niches for international travellers. The Journal of Travel and Tourism Studies, 9(2), 2-13.

Andereck, K. L., \& Vogt, C. A. (2000).The Relationship between Residents' Attitudes towards Tourism and Tourism Development Options. Journal of Travel Research, 39, 27-36. http://dx.doi.org/10.1177/004728750003900104 
Ap, J. (1992). Residents' perceptions on tourism impacts. Annals of Tourism Research, 19(4), 665-690. http://dx.doi.org/10.1016/0160-7383(92)90060-3

Aref, F., Redzuan, M. R., \& Gill, S. S. (2009). Dimensions of community capacity building: A review of its implications in tourism development. Journal of American Science, 5(8), 74-82.

Bagozzi R. P., \& Yi, Y. (1988).On the evaluation of structural equation models. Journal of Academy and Marketing Science, 16, 74-94. http://dx.doi.org/10.1007/BF02723327

Bao, J., \& Su, X. (2004). Studies on tourism commercialization in historic towns. ACTA Geographic Sinica, 59(3), 427-436.

Batra, G., \& Kaur, N. (1996). New vistas in reducing the conflicts between tourism and the environment: an environment audit approach. Managerial Auditing Journal, 11, 3-10. http://dx.doi.org/10.1108/02686909610119985

Bredenhann, J., \& Wickens, E. (2004). Tourism routes as a tool for the economic development of rural areas vibrant hope or impossible dream? Tourism Management, 15, 13-22.

Brohman, J. (1996). New directions in tourism for third world development. Annals of Tourism Research, 23(1), 48-70. http://dx.doi.org/10.1016/0160-7383(95)00043-7

Buckley, R. C. (1994).A framework for ecotourism. Annals of Tourism Research, 21, 661-665. http://dx.doi.org/10.1016/0160-7383(94)90126-0

Cavus, S., \& Tanrisevdi, J. (2002). Residents Attitudes towards Tourism: A Case Study of Kusadasi, Turkey. Tourism Analysis, 7(4), 259-268.

Chin, W. W. (1998). The partial least squares approach to structural equation modeling. In G. A. Marcoulides (Ed.), Modern business research methods. Mahwah, NJ: Lawrence Erlbaum Associates.

Chin, W. W. (2010). How to write up and report PLS analyses. In V. Esposito Vinzi, W. W. Chin, J. Henseler, \& H. Wang (Eds.), Handbook of partial least squares: Concepts, methods and application (pp. 645-689). New York: Springer. http://dx.doi.org/10.1007/978-3-540-32827-8_29

Diedrich, A., \& Garc1'a-Buades, E. (2008). Local perceptions of tourism as indicators of destination decline. Tourism Management, 1-10.

Doxey, G. V. (1975). A Causation Theory of Visitor-Resident Irritants, Methodology, and Research In-ferences. Sixth Annual Conference Proceedings of the Travel Research Association: San Diego, CA. 195-198.

Dyer, S., Gursoy, B., Sharma, \& Carter. (2007). Structural Modelling of Resident Perceptions of Tourism and Associated Development on the Sunshine Coast, Australia. Tourism Management, 28(2), 409-422. http://dx.doi.org/10.1016/j.tourman.2006.04.002

Eshliki, S. A., \& Kaboudi, M. (2012). Community perception of tourism impacts and their perception in tourism planning: A case study of Ramsar, Iran. Procedia-Social and Behavioral Sciences, 36, 333-341. http://dx.doi.org/10.1016/j.sbspro.2012.03.037

Falkner, B., \& Tideswell, C. (1997). A Framework for Monitoring Community Impact of Tourism. Journal of Sustainable Tourism, 5(1), 3-28. http://dx.doi.org/10.1080/09669589708667273

Fornell, C., \& Bookstein, F. L. (1982). Two structural equation models: LISREL and PLS applied to consumer exit-voice theory. Journal of Marketing Research, 19, 440-452. http://dx.doi.org/10.2307/3151718

Fornell, C., \& Larcker, D. F. (1981, February). Evaluating Structural Equation Models with Unobservable Variables and Measurement Error. Journal of Marketing Research, 18, 39-50. http://dx.doi.org/10.2307/3151312

Gefen, D., Straub, D. W., \& Boudreau, M. C. (2000). Structural Equation Modeling and Regression: Guidelines for Research Practice. Communications of the Association for Information Systems, 4(7), 1-70.

Ghaderi, Z., \& Henderson, J. C. (2012). Sustainable rural tourism in Iran: A perspective from Hawraman Village. Tourism Management Perspectives, 2(3), 47-54. http://dx.doi.org/10.1016/j.tmp.2012.03.001

Greaves, N., \& Skinner, H. (2010). The importance of destination image analysis to UK rural tourism. Marketing Intelligence \& Planning, 28(4), 486-507. http://dx.doi.org/10.1108/02634501011053586

Gursoy, D., Jurowski, C., \& Uysal, M. (2002). Resident Attitudes: A Structural Modeling Approach. Annals of Tourism Research, 29(1), 79-105. http://dx.doi.org/10.1016/S0160-7383(01)00028-7 
Hair, J. F., Hult, G. T. M., Ringle, C. M., \& Sarstedt, M. (2014). A Primer on Partial Least $\quad$ Squares Structural Equation Modeling, Sage, Thousand Oaks, CA.

Harrill, R. (2004). Residents' attitudes toward tourism development: A literature review with implications for tourism planning. Journal of Planning Literature, 18(3), 251-266. http://dx.doi.org/10.1177/0885412203260306

Henseler, J., Ringle, C. M., \& Sinkovics, R. R. (2009). The use of partial least squares path modelling in international marketing. Advances in International Marketing, 20, 277-320. http://dx.doi.org/10.1108/S1474-7979(2009)0000020014

Herbert, D. (2001). Literary places, tourism and the heritage experience. Annals of Tourism Research, 28(2), 312-333. http://dx.doi.org/10.1016/S0160-7383(00)00048-7

Huang, Y., \& Stewart, W. P. (1996). Rural tourism development: shifting basis of community solidarity. Journal of Travel Research, 36(4), 26-31. http://dx.doi.org/10.1177/004728759603400404

Hull, R. B., \& Revell, G. R. B. (1989). Cross-cultural comparison of landscape scenic beauty evaluations: A case study in Bali. Journal of Environmental Psychology, 9, 177-191. http://dx.doi.org/10.1016/S0272-4944(89)80033-7

Jaal, Z., \& Abdullah, J. (2012). Users' Preferences of Highway Landscapes in Malaysia: A Review and Analysis of the Literature. Procedia - Social and Behavioral Sciences, 36, 265-272. http://dx.doi.org/10.1016/j.sbspro.2012.03.029

Jamaludin, M., Othman, N., \& Awang, A. R. (2012). Community Based Homestay Programme: A Personal Experience. Procedia - Social and Behavioral Sciences, 42, 451-459. http://dx.doi.org/10.1016/j.sbspro.2012.04.210

Ko, D. W., \& Stewart, W. P. (2002). A Structural Equation Model of Residents' Attitudes for Tourism Development. Tourism Management, 23(5), 521-530. http://dx.doi.org/10.1016/S0261-5177(02)00006-7

Kuvan, Y., \& Akan, P. (2005). Residents' attitudes toward general and forest-related impacts of tourism: The case of Belek, Antalya. Tourism Management, 26(5), 691-706. http://dx.doi.org/10.1016/j.tourman.2004.02.019

Liu, J. C., Sheldon, P. J., \& Var, T. (1987). Resident perceptions of the environment impacts of tourism. Annals of Tourism Research, 14, 17-37. http://dx.doi.org/10.1016/0160-7383(87)90045-4

Mason, P. (2000). The World Wide Fund for Nature Arctic Tourism Project, Chapter 5. In B. Bramwell, \& B. Lane (Eds.), Tourism Collaboration and Partnerships: Politics, Practice and Sustainability (pp. 98-116). Channel View Publications, New York.

McCool, S. F., \& Martin, S. R. (1994). Community Attachment and Attitudes towards Tourism Development. Journal of Travel Research, 32(3), 29-34. http://dx.doi.org/10.1177/004728759403200305

Mohammed, M. D. (2002). The Ecotourism Development in Malaysia, chapter in Linking Green Productivity to Ecotourism: Experience in the Asia Pacific Region. Published by Green Productivity, Tokyo.

Murphy, P. (1985). Tourism: A Community Approach. London: Routledge.

Nunkoo, R., \& Ramkissoon, H. (2010). Small island urban tourism: a residents' perspective. Current Issues in Tourism, 13(1), 37-60. http://dx.doi.org/10.1080/13683500802499414

Nunnally, J. C. (1978). Psychometric Theory. New York, NY: McGraw-Hill.

Razzaq, A. S. A., Hadi, M. Y., Mustaa, M. Z., Hamzah, A., Khalifah, Z., \& Mohamad, N. H. (2011). Local community participation in homestay program development in Malaysia. Journal of Modern Accounting and Auditing, 7(12), 1418-1429.

Richards, G. (1996). Cultural Tourism in Europe. Wallingford, CAB International.

Riganti, P., \& Nijkamp, P. (2007). A multi-attribute experimental choice analysis of willingness to-wait in Amsterdam. Retrieved from http://dare.ubvu.vu.nl/bitstream/1871/10905/1/20070009.pdf

Ruiz-Molina, M. E., Gil-Saura, I., \& Moliner-Velázquez, B. (2010). The role of information technology in relationships between travel agencies and their suppliers, Journal of Hospitality and Tourism Technology, l(2), 144. http://dx.doi.org/10.1108/17579881011065047

Silberberg, T. (1995). Cultural Tourism and Business Opportunities for Museums and Heritage Sites. Tourism Management, 16(5), 361-365. http://dx.doi.org/10.1016/0261-5177(95)00039-Q 
Song, H. J., Lee, C. K., Kang, S. K., \& Boo, S. J. (2012). The Effects of environmentally friendly perceptions on festival visitors' decision-making process using an extended model of goal-directed behavior. Tourism Management, 22, 1417-1428. http://dx.doi.org/10.1016/j.tourman.2012.01.004

Tenenhaus, M., Vinzi, V. E., Chatelin, Y.-M., \& Lauro, C. (2005). PLS path modeling. Computational Statistics and Data Analysis, 48(1), 159-205. http://dx.doi.org/10.1016/j.csda.2004.03.005

Tsonis, L. J. (2008). Ecotourism Development: Government, Industry and Community Linkages. Proceedings from the Asia Pacific Tourism Association (APTA) 2008 Conference, 9-12 July 2008, Bangkok, Thailand.

Tuohino, A., \& Hynonen, A. (2001). Ecotourism - imagery and reality. Reflections on concepts and practices in Finnish rural tourism. Nordia Geographical Publications, 30(4), 21-34.

Twining-Ward, L., \& Butler, R. (2002). Implementing STD on a Small Island: Development and Use of Sustainable Tourism Development Indicators in Samoa. Journal of Sustainable Tourism, 10(5), 363-387. http://dx.doi.org/10.1080/09669580208667174

Wetzels, M. G. M., Lindgreen, A., de Ruyter, K., \& Wouters, J. (2005). The effect of corporate image and service delivery on customer evaluative judgments in service organizations: Analyzing an experimental study using partial least square. In F. Bliemel, A. Eggert, G. Fassott, \& J. Henseler (Eds.), Handbuch PLS-pfadmodellerung: Methode, anwendung, praxisbeispiele (pp. 225-240). Stuttgart: Schaffer-PoeschelVerlag.

Wetzels, M., Schroder, G. O., \& Oppen, V. C. (2009). Using PLS path modeling for assessing hierarchical construct models: Guidelines and empirical illustration. MIS Quarterly, 33(1), 177-195.

Zhong, L., Deng, J., Song, Z., \& Ding, P. (2011). Research on environmental impacts of tourism in China: Progress and prospect. Journal of Environmental Management, 92, 2972-2983. http://dx.doi.org/10.1016/j.jenvman.2011.07.011

\section{Copyrights}

Copyright for this article is retained by the author(s), with first publication rights granted to the journal.

This is an open-access article distributed under the terms and conditions of the Creative Commons Attribution license (http://creativecommons.org/licenses/by/3.0/). 